\title{
Johan Kraftman ja varhaisen kansalaisyhteiskunnan rakentaminen esiteollisena aikana
}

\author{
Ella Viitaniemi
}

Johan Kraftman (1713-1791) tunnetaan suomalaisessa historiankirjoituksessa ensimmäisenä henkilönä, joka aloitti taloustieteen luennot Turun akatemiassa 1740luvulla. Kraftmanin elämänkaari muotoutui erityisesti vanhakantaisen maatalouden uudistamistyön ympärille, mutta hänen vaikutuksensa oli yhteiskunnallisesti paljon laajempi. Hänen ajattelussaan lomittuvat rationalismi, pyrkimys taloudellisten ja sosiaalisten kysymysten tehokkaaseen ratkaisemiseen sekä sisäinen palo, jota määrittelivät erityisesti pietismi ja paternalismi. ${ }^{1}$

Artikkelissa käytetään Johan Kraftmanin toimia esimerkkitapauksena, jonka kautta tarkastellaan varhaisen kansalaisen toimintaa sekä pyrkimyksiä varhaisen kansalaisyhteiskunnan rakentamiseksi. 1700-luvulla kansalainen (medborgare) miellettiin henkilöksi, jolla oli sekä halua että kykyä toimia isänmaan parhaaksi. Hän ei toiminut ainoastaan omaksi yksityiseksi edukseen, vaan hän etsi erilaisia mahdollisuuksia yhteisen hyödyn edistämiseksi. ${ }^{2}$ Varhaisen kansalaisuuden käsite on siis läheisesti kytköksissä patriotismiin. Kansalainen ei kuitenkaan ollut pelkästään

\footnotetext{
${ }^{1}$ Lars Sacklén, "Framledne Professorens och Riddarens af Kongliga Wasa Orden Johan Kraftmans Lefwernes Beskrivning", Åbo Tidningar 1792, no 30-34; Pentti Virrankoski, "Kraftman, Johan (17131791)", Kansallisbiografia-verkkojulkaisu, Studia Biographica 4, Suomalaisen Kirjallisuuden Seura, Helsinki, 2000 (viitattu 25.8.2020), URL: http://urn.fi/urn:nbn:fi:sks-kbg-000402; Yrjö Kotivuori, Ylioppilasmatrikkeli 1640-1852: Johan Kraftman, Verkkojulkaisu, 2005, URL: https://ylioppilasmatrikkeli.helsinki.fi/henkilo.php?id=5888.

${ }^{2}$ Jonas Nordin, Ett fattigt men fritt folk. Nationell och politisk självbild i Sverige från sen stormaktstid till slutet av frihetstiden, Symposion Brutus Östlings bokförlag, Eslöv, 2000, 96-97; Kari Saastamoinen, "Johdatus poliittisiin käsitteisiin uuden ajan alun Ruotsissa", Käsitteet liikkeessä. Suomen poliittisen kulttuurin käsitehistoria, toim. Matti Hyvärinen, Jussi Kurunmäki, Kari Palonen, Tuija Pulkkinen \& Henrik Stenius, Vastapaino, Tampere, 2003, 47-49; Charlotta Wolff, Noble conceptions of politics in eighteenth-century Sweden (ca 1740-1790), Suomalaisen Kirjallisuuden Seura, Helsinki, 2008; Joachim Östlund, Lyckolandet. Maktens legitimering $i$ officiell retorik från stormaktstid till demokratins genombrott, Sekel, Lund, 2007, 167-77. Käytän termiä "varhainen kansalainen" erotukseksi myöhemmästä, 1800-luvun nationalismiin kietoutuneesta kansalaisuuden käsitteestä.
} 
poliittinen toimija vaan myös henkilö, jonka toimintaa ohjasi moraalinen velvollisuus ja uskollisuus yhteisöä kohtaan. ${ }^{3}$

Ruotsin valtakunnan hyvinvointi ja edistys olivat jatkuvasti esillä julkisessa keskustelussa vapaudenajalta kustavilaiselle ajalle. Valtakunnan etua korostettiin kaiken poliittisen, taloudellisen ja tieteellisen toiminnan ylimpänä ohjenuorana. Ruotsissa talousopilla ja hyötyajattelulla oli vahva asema sekä akatemiassa ja käytännön politiikassa. Akateemisessa talousopissa tehtiin käytännöllisiä sovelluksia ja niitä myös pyrittiin toteuttamaan paikallistasolla. Erityisesti maatalouden kehittäminen oli tieteellisen mielenkiinnon ja toiminnan kohteena, sillä esiteollinen yhteiskunta eli käytännössä maataloudesta. Keskustelut taloudellisten edellytysten ja olosuhteiden kehittämisestä yhdistyivät tieteeseen ja ajankohtaiseen yhteiskuntapolitiikkaan, jota ruokki aktiivinen valtiopäivätoiminta sekä erilaisten tieteellisten seurojen synty. Samaan aikaan perustettiin uusia lehtiä ja julkaistiin lukuisia pienpainatteita, jotka edesauttoivat ajatusten nopeampaa leviämistä. Ajankohtaisia taloustieteellisiä sekä yhteiskuntapoliittisia keskusteluja, joissa pohdittiin parhaita mahdollisia ratkaisuja yhteiskunnan kehittämiseksi, käytiin eri yhteisöjen välillä. Näin syntyi julkisia keskusteluja ja väittelyjä sanomalehdissä ja pienpainatteissa. Keskusteluja voitiin jatkaa kasvokkain myös valtiopäivillä, erilaisissa yhteisöissä ja seuroissa, kahviloissa ja kievareissa, mutta myös maaseutupappiloissa, herraskartanoissa ja kirkonmäillä. ${ }^{4}$

3 Bo Lindberg, "Den förmoderna offentligheten. En begreppshistorisk exposé", Förmoderna offentligheter. Arenor och uttryck för politisk debatt 1550-1830, red. Leif Runefelt \& Oskar Sjöström, Nordic Academic Press, Lund, 2014, 34-36. Wolff, Noble conceptions of politics, 70-84. Varhaisesta nationalismista (ennen 1780-lukua) esimerkiksi Harald Gustafsson, ”De överlappande pusslen. Om partikularistiska och multietniska konglomeratstater i det tidigmoderna Europa", Maktens mosaik. Enhet, särart och självbild $i$ det svenska riket, red. Max Engman \& Nils Erik Villstrand, Svenska litteratursällskapet i Finland, Helsinki \& Atlantis, Stockholm, 2008, 59-73; Juha Manninen, Valistus ja kansallinen identiteetti. Aatehistoriallinen tutkimus 1700-luvun Pohjolasta, Suomalaisen Kirjallisuuden Seura, Helsinki, 2000; Nordin, Ett fattigt men fritt folk. Poliittisen kulttuurin kehityksestä 1700-luvun Ruotsissa mm. Pasi Ihalainen, Michael Bregnsbo, Karin Sennefelt \& Patrik Winton (eds), Scandinavia in the Age of Revolution. Nordic political cultures 1740-1820, Ashgate, Farnham, 2016; Pasi Ihalainen, Agents of the people. Democracy and popular sovereignty in British and Swedish parliamentary and public debates, 1734-1800, Brill, Leiden, 2010; Karin Sennefelt, Politikens hjärta. Medborgarskap, manlighet och plats $i$ frihetstidens Stockholm, Stockholmia, Stockholm, 2011; Ella Viitaniemi, Yksimielisyydestä yhteiseen sopimiseen. Paikallisyhteisön poliittinen kulttuuri ja Kokemäen kivikirkon rakennusprosessi 1730-1786, Tampereen yliopisto, Tampere, 2016; Patrik Winton, Frihetstidens politiska praktik. Nätverk och offentlighet 1746-1766, Uppsala universitet, Uppsala, 2006.

${ }^{4}$ Jari Niemelä, Vain hyödynkö tähden? Valistuksen ajan hyötyajattelun, luonnontieteen ja talouspolitiikan suhde Pehr Adrian Gaddin elämäntyön kautta tarkasteltuna, Suomen Historiallinen Seura, Helsinki, 1998, 11, 59-62; Jouko Nurmiainen, Edistys ja yhteinen hyvä vapaudenajan ruotsalaisessa poliittisessa kielessä, Suomalaisen Kirjallisuuden Seura, Helsinki, 2009, 211; Päivi Maria Pihlaja, Tiedettä pohjantähden alla. Pohjoisen tutkimus ja Ruotsin tiedeseurojen suhteet Ranskaan 1700-luvulla, Societas Scientiarum Fennica, Helsinki, 2009, 9-13, 38-39. Katsaus talouden uudistamiseen liittyvästä käsitehistoriallisesta keskustelusta Sami Louekari, Hyödyn politiikka. Kokemäenjoen ympäristöhistoriaa 1720-1850, Turun yliopisto, Turku, 2013, 59-64. Esimerkiksi Paloposki ja Virrankoski käyttävät termiä "esifysiokratia" ja "reformimerkantilismi", jolla he kuvaavat siirtymää pois vanhakantaisesta merkantilismista kohti vapaampaa talouselämää ja yhteiskuntapoliittista ajattelua 1740-luvun jälkipuoliskolta lähtien. Toivo Paloposki, Suomen talouden kehittäminen 1750-1760-lukujen valtiopäiväpolitiikassa, Suomen Historiallinen Seura, Helsinki, 1976, 54-57; Pentti Virrankoski, Anders Chydenius. Demokraattinen poliitikko valistuksen vuosisadalla, WSOY, Helsinki, 1986, 89-91. Tiedon siirtämisestä varhaismodernissa yhteiskunnassa mm. Esko M. Laine \& Minna Ahokas (toim.), Hyödyllisen tiedon piirit. Tutkimuksia papistosta, rahvaasta ja tiedon rakentumisesta 1700-luvulla, Suomalaisen Kirjallisuuden Seura, Helsinki, 2018 ja Ella Viitaniemi, "Muurarimestari Kustaa Stenman ja katumaton maailma. Pietismi, kirjoittaminen 
Artikkelissa keskeistä on varhaisen kansalaisyhteiskunnan rakentaminen, joka kietoutuu lähteisesti samanaikaiseen poliittisen ja kirjallisen julkisuuden sekä yleisen keskustelun ja mielipiteiden syntyyn. Tämä tapahtui 1700-luvun jälkipuoliskolla Ruotsin valtakunnassa provinsseissa, myös kauempana Tukholmasta tai yliopistokaupungeista. ${ }^{5}$ Vapaudenajalla poliittisen julkisuuden katse luotiin ruohonjuuritasolle. Hyötyajattelun ja fysiokratian periaatteiden mukaisesti pyrittiin ratkaisemaan kysymyksiä, jotka estivät valtakunnan talouden kehitystä. Näihin ongelmiin etsittiin varsin konkreettisia ja käytännöllisiä vastauksia esimerkiksi maatalouden tuottavuuden kohentamiseen liittyen. Näin ollen valtakunnan poliittiset ja taloudelliset kysymykset ja pyrkimykset tulivat 1700-luvun jälkipuoliskolla varsin lähelle kansaa ja heidän arkielämäänsä. Kansan elämään vaikuttivat isoajakoa, torppien perustamisoikeuksia, koskenperkauksia ja palveluspakkoa koskevat asetukset ja uudistukset. $^{6}$

Kraftmanin toiminnassa korostuu vanhakantaisen yhteiskunnan toimintatapojen uudistaminen ja tehostaminen. Hänen erilaiset toimensa kuvaavat hyvin 1700-luvun jälkipuoliskon vahvan edistysuskon ja hyötyajattelun leimaamaa aikakautta, jossa kaikki toiminta on suunnattu isänmaan taloudellisten olojen kohentamiseksi. Kraftmanin tavoitteena oli ollut ura yliopistossa, mutta hän ei onnistunut saamaan tavoittelemiaan professorinvirkoja Turun akatemiassa, joten hän otti vuonna 1748 vastaan Porin triviaalikoulun rehtorin tehtävän. Vuonna 1752 Kraftman nimitettiin ylimääräiseksi matematiikan professoriksi Turun akatemiaan, mutta käytännössä hän hoiti virkaa vain kahden vuoden ajan. Tehtävä ei miellyttänyt Kraftmania, ja hän anoi vapautusta, jonka konsistori lopulta myönsi. Toimettomaksi Kraftman ei kuitenkaan jäänyt, vaan hänen elämäntyönsä tapahtui pääosin yliopiston ulkopuolella. ${ }^{7}$

Porin seudulla asuessaan Kraftman ideoi ja toteutti monia edistyksellisiä hankkeita ja uudistuksia, jotka olivat vastauksia ajankohtaisiin valtakunnallisiin ja yleiseurooppalaisiin kysymyksiin yhteiskunnan ja maatalouden tilan kohentamisesta. Merkittävimpiä hankkeita olivat hänen johtamansa Lattomeren suonkuivatus sekä

ja kokemuksen siirtäminen länsisuomalaisella maaseudulla 1700-luvun jälkipuoliskolla”, Eletty historia. Kokemus näkökulmana menneisyyteen, toim. J. Annola, V. Kivimäki, A. Malinen, Vastapaino, Tampere, 2019.

${ }^{5}$ Jürgen Habermas, Julkisuuden rakennemuutos. Tutkimus yhdestä kansalaisyhteiskunnan kategoriasta, suom. Veikko Pietilä, Vastapaino, Tampere, 2004, 47-91; Raimo Huttunen, ”Jürgen Habermasin yhteiskuntateoriat", 1900-luvun saksalainen yhteiskuntateoria, toim. Ilkka Kauppinen, Miikka Pyykkönen \& Olli-Pekka Moisio, Gaudeamus, Helsinki, 2019, 148. Habermasin julkisuusparadigman käytöstä ja sen problematiikasta Ruotsin valtakunnan 1700-luvun poliittisen kulttuurin tutkimuksessa mm. Sennefelt, Politikens hjärta, 20-21; Viitaniemi, Yksimielisyydestä yhteiseen sopimiseen, 32-33.

${ }^{6}$ 1700-luvun maataloushistoriaan liittyen on viime aikoina julkaistu varsin mielenkiintoisia teoksia kuten Kirsi Laine, Maatalous, isojako ja talonpoikainen päätöksenteko Lounais-Suomessa 1750-1850, Suomen maatalousmuseo Sarka, Loimaa, 2020; Louekari, Hyödyn politiikka; Jani Marjanen, Den ekonomiska patriotismens uppgång och fall. Finska hushållningssällskapet i europeisk, svensk och finsk kontext 17201840, Helsingin yliopisto, Helsinki, 2013; Riikka Miettinen \& Ella Viitaniemi (toim.), Reunamailla. Tilattomat Länsi-Suomen maaseudulla 1600-1800, Suomalaisen Kirjallisuuden Seura, Helsinki, 2018; Petri Talvitie, Kyläomistuksesta yksityiseen maanomistukseen. Isojako Länsi-Uudellamaalla 1700-luvulla, Helsingin yliopisto, Helsinki, 2013; Petri Talvitie, Taistelu perintökirjasta. Talonpojat, aateli ja kruununtilojen perinnöksiostot 1700-luvun Suomessa ja Ruotsissa, Suomalaisen Kirjallisuuden Seura, Helsinki, 2020.

${ }^{7}$ Sacklén, "Framledne Professorens och Riddarens af Kongliga Wasa Orden Johan Kraftmans Lefwernes Beskrivning"; Virrankoski, "Kraftman, Johan"; Kotivuori, Ylioppilasmatrikkeli 1640-1852: Johan Kraftman. 
uudenlaisten kivinavettojen eli ns. härkätallien vuosia kestänyt kehitystyö. Kraftman julkaisi hankkeistaan useita maatalouspoliittisia tekstejä ja raportteja, jotka oli tarkoitettu muiden vastaavien projektien esimerkeiksi ja ohjeiksi.

Kraftman osallistui kirjoituksillaan myös muihin ajankohtaisiin yhteiskuntapoliittisiin keskusteluihin, kuten kysymyksiin maatalouden työvoimapulasta ja kaskeamisoikeudesta. Työvoimakysymyksessä Kraftmanilla oli varsin ankara ja holhoava näkemys, joka korostuu vielä entisestään, kun sitä verrataan Anders Chydeniuksen (1729-1803) samanaikaisiin varsin humaaneihin ja luonnonoikeutta korostaviin kirjoituksiin. ${ }^{8}$ Toisaalta Kraftman osoitti tuntevansa talonpoikien haasteet vanhakantaisen maatalouden piirissä kaskenpolttokysymyksessä ja puolusti suomalaisten erityisoikeutta kaskenpolttoon toimeentulon turvaamiseksi. ${ }^{9}$ Kraftman toimi lisäksi aktiivisena paikallispoliittisena vaikuttajana Ala-Satakunnan alueella ja teki muun muassa useita aloitteita Ulvilan maaseurakunnan ja Porin kaupungin asioiden eteenpäinviemiseksi. Kraftman aloitti monet projektinsa yksityisesti, mutta sai myöhemmin erityisesti laajaan suonkuivatustyöhön keskushallinnon tuen. Suurimmat tunnustukset Kraftmanin sai, kun hänet kutsuttiin vuonna 1775 Vaasan ritarikuntaan sekä nimitettiin vuonna 1778 Ruotsin tiedeakatemian jäseneksi.

Tässä artikkelissa avaan Johan Kraftmanin esimerkin kautta sitä, miten hänen työnsä, yhteiskunnallinen toimintansa sekä erilaiset kirjalliset tuotoksensa osaltaan rakensivat poliittista ja kirjallista julkisuutta sekä loivat uudenlaista keskustelua sekä valtakunnallisesti että paikallistasolla. Artikkelissa ei käydä läpi Kraftmanin koko kirjallista tuotantoa, pitkää elämänkaarta moninaisine tehtävineen ja verkostoja tai vaikutuspiirejä. Sen sijaan tarkastelen Kraftmanin toimia kolmen keskeisen sektorin kautta, jotka koskevat koulutuksen ja maatalouden kehittämistä sekä aloitteita paikallispolitiikan saralla. Nämä esimerkit avaavat uudenlaisen näkökulman poliittisen kulttuurin kehitykseen ja julkisuuden muodostumiseen ja ennen kaikkea osoittavat pyrkimyksiä varhaisen kansalaisyhteiskunnan (borgerliga samhället) rakentamiseksi. ${ }^{10}$ Artikkelin pohjaksi valittu lähdeaineisto koostuu Kraftmanin julkisluonteisista kirjeistä ja sekä hänen omista että aikalaisten julkaisuista, jotka kuvaavat Kraftmanin toimia poliittisen julkisuuden ja yhteiskunnan rakentamisen näkökulmista.

Valistukseen liittyy ajatus yleisen ja yhteisen mielipiteen synnystä, jota ohjaa järki. Fysiokraattisen ajattelun mukaan ennen pitkään totuus tultaisiin tietämään ja maailmaa voitiin johtaa sen mukaiseen edistykseen. ${ }^{11}$ Näin ollen oikean tiedon tuottaminen, kirjoittaminen, tekstien julkaiseminen ja mielipiteiden muokkaus poliittisessa julkisuudessa johtaisi lopulta järjen ja parhaan ratkaisun voittoon. Artikkelissa osoitan, miten provinssikaupungit, maaseutu ja paikallistason poliittiset areenat sidottiin mukaan valtakunnallisen julkisen keskustelun ja yleisen mielipiteiden muodostumisen piiriin. Kraftmanin toiminnan esimerkit havainnollistavat hyvin, miten mielipiteitä ja

\footnotetext{
${ }^{8}$ Virrankoski, "Kraftman, Johan"; Virrankoski, Anders Chydenius.

${ }^{9}$ Sacklén, "Framledne Professorens och Riddarens af Kongliga Wasa Orden Johan Kraftmans Lefwernes Beskrivning"; Matti Klinge, Iiisalmen ruhtinaskunta. Modernin projekti sukuverkostojen periferiassa, Suomalaisen Kirjallisuuden Seura, Helsinki, 2006, 122-127; Virrankoski, "Kraftman, Johan".

10 Kansalaisyhteiskunnan (societas civilis, borgerliga samhället) käsitteen historiasta Ruotsin valtakunnassa Bo Lindberg, Den antika skevheten. Politiska ord och begrepp i det tidig-moderna Sverige. Kungliga vitterhets historie och antikvitets akademien, Stockholm 2006, 71-74.

11 Aira Kemiläinen, "Nationalismi ja patriotismi Ranskan vallankumouksen aatemaailmassa", Historiallinen Aikakauskirja 1989:4, 323.
} 
asenteita pyrittiin muokkaamaan ja muuttamaan niin valtakunnallisilla julkisilla kirjoituksilla kuin myös keskusteluilla paikallistason poliittisilla areenoilla.

Kraftmanin ajattelussa ja toiminnassa on myös vahva pietistinen ote. Se nivoutuu osaltaan varsin hyvin hyötyajatteluun, patriotismiin ja yksilönvastuuta korostavaan näkökulmaan. Pietismismissä keskeistä oli oma henkilökohtainen kääntyminen ja Raamatun lukeminen, mikä tuki ajatusta henkilökohtaisesta hengellisestä kasvusta ja vastuusta, aikaisemman yhteisöllisen uskon sijaan. Tämä ajattelu heijastui osaltaan myös fysiokratiaan ja valistuksen periaatteisiin: henkilö itse oli vastuussa teoistaan ja toimi jotakin tavoitetta kohti, oli kyse sitten hengellisestä kilvoittelusta tai isänmaan taloudellisten ja yhteiskuntapoliittisten olosuhteiden parantamisesta.

\section{Kraftman koulumiehenä ja porvarillisen yhteiskunnan rakentajana}

Johan Kraftmanin lupaavasti alkanut yliopistoura koki kolauksen, kun hänen tavoittelemansa Turun akatemian ensimmäinen taloustieteen professuuri annettiin Pehr Kalmille vuonna $1746 .{ }^{12}$ Näin ollen hän etsiytyi muualle virkatehtäviin ja hänet nimitettiin heinäkuussa 1748 Porin triviaalikoulun rehtoriksi. ${ }^{13}$ Tämä sopi sinänsä hyvin, sillä Kraftman oli jo aiemmin hankkinut itselleen Ulvilan pitäjästä lähellä Porin kaupunkia sijaitsevan Koiviston ratsutilan, jonne hän asettui asumaan vaimonsa Brita Polvianderin kanssa.

Vaikka rehtorin virka perusopetuksesta vastaavassa triviaalikoulussa oli kaukana taloustieteen professuurista, suhtautui Johan Kraftman koulun johtamiseen ja kehittämiseen kunnianhimoisesti. Kraftman nimittäin tiedosti, että yhteiskuntaa rakennettiin kouluttamalla nuoria miehiä, jotka tulisivat palvelemaan isänmaata monissa eri tehtävissä ja viroissa. Hän totesi Porin triviaalikoulussa pitämässään puheessaan heinäkuussa 1751, että koulut laskivat ensimmäisen perustuksen, jolle yhteiskunta (borgerligt samhälle) rakentui. Kraftmanin mukaan valtakunnan hyvinvointi ja menestys perustuivat erilaisten tehtävien ja toimien hyvään hoitamiseen. Siksi jo koululaisille piti opettaa kristinopin lisäksi mm. kirjoittamista, laskemista, historiaa, kieliä, teologiaa, moraalia sekä matematiikkaa ja taloustietoa (oeconomie). Tärkeää oli myös iskostaa nuorukaisiin Jumalan pelko ja oikean tiedon halu. ${ }^{14}$

Kraftman käytti puheessaan käsitettä borgerligt samhälle, joka oli ollut käytössä Ruotsin valtakunnassa jo 1700-alkupuolella. Se tarkoitti ihanteellista yhteiskuntaa, jota rakennettiin 1700-luvun kuluessa hyödyn aikakauden ja valistuksen hengessä. ${ }^{15}$ Kraftmanin mukaan porvarillisen yhteiskunnan eli käytännössä varhaisen kansalaisyhteiskunnan rakentaminen alkoi siis koulutuksella, jota annettiin paikallistasolla. Provinsseissa sijaitsevat julkiset koulut (publique lärohus) tekivät tärkeää pohjatyötä koko yhteiskunnan rakentamiseksi.

12 Kalmin ja Kraftmanin välisestä virkakilpailusta ks. Gunnar Suolahti, "Miten Pietari Kalm tuli professoriksi?" Historiallinen Aikakauskirja 1910:1, 25-26, ja Matti Klinge, Professoreita, Otava, Helsinki, 1990, 75.

${ }^{13} \mathrm{KA}$, Turun toimipiste, Turun arkkihiippakunnan tuomiokapitulin arkisto (TATA), kirjekirja BI: 16 (1748), Turun tuomiokapituli Johan Kraftmanille, 27.7.1748.

14 "Nu som et Rikets wälgång, stor och anseende grundar sig på göromålens rätta ans och skötsel: så är det och onekeligt, at skolorne lägga den första grundwal til den lycka, som et borgerligt samhälle kan fägna sig af." Johan Kraftman, Tal om läsningsverket, Hållne vid examina anniversaria i Björneborg trivial-schola, Lars Salvius, Stockholm,, 24.

${ }^{15}$ Lindberg, Den antika skevheten, 71-74; Förvaltningshistorisk ordbok: "borgerligt samhälle", URL: http://fho.sls.fi/uppslagsord/4816/borgerligt-samhalle/. 
Tiedon ja koulutuksen lisääminen olivat tärkeitä keinoja isänmaan kehittämisessä. Ruotsin valtakunnassa oli vallalla hyötyajattelu ja eräänlainen varhaisfysiokratismi 1730ja 1760-luvuilla, mikä näkyi yliopisto-opetuksessa luonnon- ja taloustieteiden nousuna ja yhteiskunnallisen ajattelun painotuksena. Turun akatemiassa luonnontieteiden käytännölliset sovellukset suuntautuivat erityisesti maanviljelyksen kehittämiseen. ${ }^{16}$ Siellä tunnettiin ja käytettiin alan viimeisintä eurooppalaista tutkimusta. ${ }^{17} \mathrm{Kraftmanin}$ aikana akatemiassa oli voimakas pyrkimys luonnontieteiden käytännön sovellusten tekemisestä suoraan talouselämän hyödyksi. Kraftmanin oppi-isän, professori Browalliuksen mukaan tieteen tuli olla läheisessä kosketuksessa jokapäiväiseen elämään ja tuottaa hyötyä isänmaalle ja ihmisille. ${ }^{18}$

Uudet taloudelliset kokeilut ja sovellukset otettiin käyttöön mahdollisimman nopeasti Turun akatemian vaikutusalueella. Papisto ja muut virkamiehet, jotka olivat opiskelleet akatemiassa ja levittäytyneet sittemmin ympäröivälle maaseudulle työtehtäviin, olivat mainio väylä kasvatuskokeilujen ja uusien menetelmien levittämiseen. Heihin istutettiin opintojensa aikana ajatus siitä, että valistuneen kansalaisen velvollisuus oli toimia isänmaan hyödyksi ja eduksi. Lisäksi erityisesti papistolla oli tiiviit verkostot ja suhteet vanhaan opinahjoonsa Turun akatemiaan. Tämä opiskeluaikana syntynyt napanuora ei katkennut, sillä papisto oli edelleen virkavuosinaan riippuvainen tuomiokapitulista, joka koostui useasta Turun akatemian eri alan professorista. ${ }^{19}$ Esimerkiksi taloustieteen professori Pehr Kalm toimi vuosia myös tuomiokapitulin jäsenenä. Lisäksi papisto kokoontui ns. pappiskokouksiin ja toimi myös yhtenä säätynä valtiopäivillä. Maaseudun virkamiehillä oli myös mahdollisuus tilata maakuntiin valtakunnallisia sanomalehtiä, joista ammentaa uutta tietoa ja vinkkejä (maa)talouden kehittämiseen liittyen.

Kun Johan Kraftman siirtyi johtamaan Porin triviaalikoulua, hän sovelsi Turun akatemiassa omaksumaansa mallia ja uudisti kouluopetusta opettamalla itse uusia aineita eli taloustietoa ja luonnonhistoriaa. Kraftman tiedosti, että hänen johtamansa triviaalikoulun oppilaista osa eteni yliopistoon ja virkamiesuralle, mutta osa myös armeijan, laivaston tai kauppahuoneiden palvelukseen. ${ }^{20}$ Heistä tuli pappeja, virkamiehiä, kauppiaita, laivureita ja upseereita, jotka toimivat monenlaisissa tehtävissä. Parhaimmillaan he tulivat hoitamaan virkansa ja tehtävänsä hyvin ja veivät oppimansa tiedot ja taidot mukanaan eripuolille valtakuntaa ja jopa sen rajojen yli, mutta erityisesti tavallisen kansan piiriin. $^{21}$

Kraftmanin tavoite isänmaan edistyksen ja varhaisen kansalaisyhteiskunnan rakentamisessa kuitenkin törmäsi erinäisiin käytännön haasteisiin. Koululaiset olivat nimittäin lähtökohdiltaan eritasoisia. Näin ollen myös koulutusta oli Kraftmanin

\footnotetext{
${ }^{16}$ Esim. Petri Karonen, Pohjoinen suurvalta. Ruotsi ja Suomi 1521-1809, WSOY, Helsinki, 1999, 337; Paloposki, Suomen talouden kehittäminen 1750-1760-lukujen valtiopäiväpolitiikassa, 54-57; Virrankoski, Anders Chydenius, 86-91.

${ }^{17}$ Klinge, Iisalmen ruhtinaskunta, 123-125.

${ }^{18}$ Virrankoski, Anders Chydenius, 61.

${ }^{19}$ Pentti Laasonen, Suomen kirkon historia 2. Vuodet 1593-1808, WSOY, Porvoo, 1991, 307.

${ }^{20} \mathrm{Kraftman}$, Tal om läsningsverket, passim. Kraftman luettelee eri ammatteja ja niissä vaadittavia taitoja, esimerkiksi matematiikan hyötyjä merenkulussa.

${ }^{21}$ 1700-luvun jälkipuoliskolle luonteenomaista oli vähittäinen "herrasväen" kasvu maaseudulla. Papiston lisäksi esimerkiksi upseeristo oli hajautettu asumaan puustelleissaan maaseudulla rykmentin alueella, isojakoatoimittavat maanmittarit liikkuivat pitäjästä toiseen ja vaurastuvat talonpojat pyrkivät kouluttamaan jälkeläisen yhä useammin.
} 
mukaan muokattava eri tarpeisiin; siviilivirkoihin, elinkeinoihin ja kirjallisiin töihin. Porin triviaalikoulu keräsi oppilaiksi erityisesti ympäröivän maaseudun poikia. Koulu ei kuitenkaan ollut merkityksetön, sillä esimerkiksi vuonna 1738 siellä oli noin 200 oppilasta. Suurin osa heistä oli alemman virkakunnan kuten upseeriston ja vauraampien talonpoikien lapsia Satakunnan alueelta. Näin ollen Porin triviaalikoulussa oli ongelmana kielikysymys. Maaseudun alin virkakunta tai ratsutilalliset eivät puhuneet kotikielenään ruotsia, ja jopa Porin kaupunki oli käytännössä suomenkielinen. Vaikka triviaalikoulun opetus ei tapahtunut enää latinaksi vaan ruotsiksi, aiheutti kieli edelleen kuitenkin haasteita sekä opettamisessa että oppimisessa. ${ }^{22}$

Kraftman kävi oppilaiden ruotsin kielen taidosta kirjeenvaihtoa tuomiokapitulin kanssa pian virkaan astuttuaan. Tuomiokapituli tuli siihen tulokseen, ettei sellaisia vanhempia poikia, jotka eivät osanneet ruotsia, pitäisi ottaa kouluun laisinkaan. Sen sijaan he olisivat sopivampia auranvarteen, sillä seudulla oli pula työvoimasta. Kyse ei kuitenkaan ollut kaikista suomenkielisistä oppilaista, vaan niistä, jotka lähetettiin kouluun vasta $15-20$-vuotiaina eli varsin myöhään. ${ }^{23}$ Kraftman linjasi myöhemmin, ettei ruotsia puutteellisesti osaavia oppilaita pitäisi ottaa ylemmälle kirjuriluokalle. Hän ymmärsi, etteivät kieliopinnot sujuneet kaikilta. Suurimmalle osalle riitti, että ruotsia opittiin triviaalikoulussa sen verran, että sillä pärjättiin tulevissa toimissa ja tehtävissä. Suomenkieliset nuoret miehet, jotka päätyivät lopulta esimerkiksi alempiin virkoihin, kauppiaiksi tai takaisin maanviljelyksen pariin, hyötyivät kuitenkin erityisesti matematiikan ja talous- ja luonnontieteen opinnoista, joissa Porin triviaalikoulu edusti aikansa huippua. ${ }^{24}$ Kouluvuosien jälkeen nuoret miehet toimivat uuden tiedon ja ajattelun välittäjänä, ja oppi kantautui laajemminkin maaseudun väestön hyödyksi.

Kraftmanin äärimmilleen viety hyötyajattelu näkyy myös monissa yksityiskohdissa, joilla hän pyrki järjestämään kouluopetusta. Yksi keskeinen kysymys oli, miten koulupoikien tulisi suhtautua koulussa ja sen ulkopuolella vietettyyn aikaan. Porin ulkopuolelta triviaalikouluun tulleet pojat asuivat yleensä kaupunkilaisten hoteissa. Kraftmanilla oli huoli siitä, miten poikien aika ja energia opiskelujen sijaan saattoi kulua iltaisin kaupungilla vaelteluun ja metelöintiin ja johti huonoon seuraan. Kraftman esittikin eräänlaisen asuntolan järjestämistä, jossa muualta tulleet koululaiset majoittuisivat opettajien valvonnan alla. Koululaisten moraalisen rappion lisäksi rehtorin pelkona oli nimittäin se, että kaupungilla remuavien nuorien kouluvuodet osoittautuisivat turhaksi ajanhaaskaukseksi eivätkä johtaisi lopulta toivottuun tiedonhankintaan, virkaan tai toimeliaisuuteen, joka edistäisi isänmaan etua. ${ }^{25}$

Kraftmania vaivasi myös se, että lukukausien välisenä aikana koululaiset unohtivat lähes kaiken koulussa oppimansa. Kesätaukonsa aikana koululaisten tuli hänen mielestään keskittyä maantietoon, kasvitietoon, piirtämiseen sekä muihin vastaaviin harjoitteisiin ja toimintoihin. Kraftman myös kehotti koulupoikia tutustumaan maanviljelykseen sekä tarttumaan vapaa-ajallaan talonpoikien tavoin lapioon ja auraan. ${ }^{26}$ Näin Kraftman myös itse toimi.

\footnotetext{
22 J. W. Ruuth, Porin kaupungin historia II, 1558-1809, uuden suomenkielisen laitoksen toimittanut Mauno Jokipii, Porin kaupunki, Pori, 1958, 530-531.

${ }^{23}$ KA Turun toimipiste, TATA, kirjekirja BI: 16 (1748), Turun tuomiokapituli Johan Kraftmanille 23.11.1748.

${ }^{24}$ Matti Walta, Virkamiehiä. Lääninhallinnon virkamiehet 1721-1708, Suomen sukututkimusseura, Helsinki, 2005, 31-32

${ }^{25}$ Ruuth, Porin kaupungin historia II, 530.

${ }^{26} \mathrm{Kraftman}$, Tal om läsningsverket , 33
} 


\section{Professori tarttuu kuokkaan ja mustekynään}

1700-luvulla politiikan, tieteen ja julkisen keskustelun keskiössä oli maatalous. Se oli esiteollisen yhteiskunnan ydintoiminta-alue ja pääelinkeino, joka vaikutti koko valtakunnan taloudelliseen tilaan ja kehitykseen. Juuri maatalous oli myös tieteellisen mielenkiinnon, kokeiden ja toiminnan kohteena, jotta sen avulla voitaisiin parantaa yhteiskunnan oloja. Ruotsin valtakunta oli menettänyt suuressa Pohjan sodassa Baltian alueet, jotka olivat tuottaneet paljon viljaa. Vielä kun hattujen sodan seurauksena oli menetetty osa Suomea, ei Suomessa tuotettu riittävästi viljaa edes oman väestön, saati sitten sotaväen ylläpitämiseksi. ${ }^{27}$ Näin ollen Ruotsin valtakunnan taloudellisen ja sen ohella myös poliittisen ja sotilaallisen tilanteen kohentamiseksi oli kiinnitettävä huomiota maatalouden tehostamiseen.

Keskustelut erilaisista keinoista Suomen taloudellisen tilanteen ja perusedellytysten kohentamiseksi kävivät kiivaina vapaudenajan valtiopäivillä. Myös monenlaisiin mittaviin uudistuksiin ryhdyttiin. Vesitiemahdollisuuksien kartoittaminen, koskenperkauksien aloittaminen, maamittaukset, isonjaon aloittaminen sekä esimerkiksi kysymykset koskien perinnöksiostoja sekä torppien perustamisoikeuksia tähtäsivät sekä (maa)talouden kehittämiseen että väestönkasvun edistämiseen. ${ }^{28}$

Talousajattelijat, jotka toimivat niin valtiopäivillä kuin yliopistoilla, näkivät selkeästi tarpeen, miten monin eri tavoin vanhakantaista maataloutta voitaisiin tehostaa. Maatalouden kehityksen esteenä olivat kuitenkin tiedon puute sekä työvoimapula. Kaikki työt vaativat monia käsipareja lisää. Kraftmanin aikalainen, Pehr Adrian Gadd (1727-1797) kirjoitti kuvauksen Ylä-Satakunnan taloudellisista oloista 1750-luvulla ja totesi "...Ensiksikin puuttuu heiltä tarpeellista tietoa tästä asiasta [heinänviljely] ja toiseksi on täällä myös liian vähän väkeä, mutta paljon tekemistä. Onnellisempi aika, jolloin ei ole kumpaakaan näitä puutteita, saanee edukseen aikaan tämän ynnä paljon muuta." 29

Näihin keskeisiin ongelmiin myös Kraftman tarttui maatalouteen painottuvassa elämäntyössään: oikean tiedon lisäämiseen, resurssienkäytön tehostamiseen sekä työvoiman ohjaamiseen. Kraftmanin keinoina oli tehdä käytännön kokeita siitä, miten eri maatalouteen liittyviä töitä kannatti tehdä, miten työtehoa voitiin maksimoida sekä parantaa viljelymenetelmiä. Kraftmanin toiminta muistutti enemmänkin insinööritaitoa ja tekniikkaa kuin nykykäsityksen valossa tapahtuvaa taloustiedettä. Hänen voidaankin sanoa edustaneen yhteiskuntahyödyn saavuttamisen näkökulmaa enemmänkin kuin tiedettä. ${ }^{30}$ Tavoitteena hänelläkin oli kuitenkin valistuksen hengessä oikean tiedon etsiminen, parhaan argumentin voitto sekä lopulta vanhakantaisten mielipiteiden muokkaaminen ja käytännön muutokset. Huomattavaa kuitenkin on, että Kraftmanin elämäntyö yhteiskunnallisena vaikuttajana ja maataloudenkehittäjänä tapahtui pääosin yliopistouran ulkopuolella.

\footnotetext{
${ }^{27}$ Ilkka Teerijoki, Nälkävuosien turva? Pitäjänmakasiinit Suomessa 1700-luvulla, Suomen Historiallinen Seura, Helsinki, 1993, 22-23.

${ }^{28}$ Paloposki, Suomen talouden kehittäminen 1750-1760-lukujen valtiopäiväpolitiikassa, passim.

${ }^{29}$ Pehr Adrian Gadd, Satakunnan kihlakuntain pohjoisosan taloudellisen kuvaamisen yritys, joka käsittää huomautuksia maantieteen, muinaismuistojen, fysiikan, luonnonhistorian ja talouden ym. aloilta tarpeellisine piirroksineen, suom. Kaapo Murros, Tampereen historiallinen seura, Tampere, 1946, 127.

${ }^{30}$ Pihlaja, Tiedettä pohjantähden alla, 39.
} 
Kraftmanin kotina ja maatalouskokeiden tukikohtana oli 2 1/3 manttaalin Koiviston ratsutila Ulvilassa, jonka hän omisti vuodesta 1744 alkaen. ${ }^{31}$ Sacklénin mukaan Koiviston tila oli Kraftmanin hankkiessa sen varsin huonossa kunnossa. Niityillä ja laitumilla seisoi vesi ja ne olivat osin metsittyneet. Vastaavasti metsäosuudet olivat märkiä ja huonosti hoidettuja. Tilaa viljeli neljä lampuotia ja neljä torpparia, jotka kärsivät huonoista sadoista, eivätkä he uskoneet, että hiekkapitoisesta maasta edes parempia satoja saataisiinkaan. ${ }^{32}$ Kraftman aloitti pahoin rappeutuneen Koiviston tilan kohentamisen ja maatalouden tehostamisen, ja hänen toiminnallaan oli lopulta merkittävää vaikutusta myös koko seudulle. Hän tutustui perin pohjin maatalouteen ja yritti rationalisoida työtapoja sekä muokata olosuhteita ja tiloja, jotta maanviljelyksen tuottavuus nousisi.

Kraftman organisoi Koiviston työt uudella tavalla, joka tähtäsi tilan tuottavuuden kasvuun. Aiemmin tila oli ollut talonpoikaisten vuokraviljelijöiden hoidossa omistajan itsensä asuessa muualla. Kraftman viljeli itse osaa, mutta piti tilalla myös viisi lampuotia. Lisäksi Koivistoon perustettiin uusia torppia siten, että vuonna 1771 torppareita oli 11 ja vuonna $179015 .{ }^{33}$ Kartanoiden koon ja tuottavuuden avaintekijänä olikin nimenomaan torppien perustaminen ja niistä saatava, käytännössä ilmainen, työvoima. Torpparit tekivät vuokraamaansa maapalaa vasten kartanolle kaksi päivätyötä viikossa ja toimittivat erilaisia maatalouden tuotteita torpasta solmitun kontrahdin ehtojen mukaan. Kraftman myös pestasi aluksi lisää renkejä, joita tarvittiin peltojen ja niittyjen muokkaus- ja raivaustöissä. ${ }^{34}$

Kraftmanin pääintressi olikin nimenomaan maatalouden tieteellinen ja käytännöllinen kehittäminen ja siitä kirjoittaminen, julkaiseminen ja valistaminen. Koivisto toimi mallitilana muille viljelijöille, niin säätyläisille kuin talonpojillekin. Se toimi myös koetilana, jossa professori etsi parhaita mahdollisia ratkaisuja. Kuten Sami Louekari on todennut, Koiviston tilaan ei kuulunut sahaa, kauppapurjehdusta tai muuta erillistä liiketoimintaa. ${ }^{35}$ Kraftman ei ollut erityisen kiinnostunut eksoottisista kasvikokeiluista eikä hän haaveillut silkkitehtaiden perustamisesta pohjolaan. Sen sijaan hän havaitsi, että Suomen vaativissa ilmasto-olosuhteissa on parempi keskittyä perinteisen maanviljelyn edellytysten kehittämiseen.

Vanhan viljanviljelyyn keskittyneen maatalouden kehittämisen pullonkaulana oli lannoitteiden vähyys. Parempia viljasatoja saatiin käyttämällä enemmän lannoitusta, mutta lantaa saatiin riittävästi vain, mikäli karjaa ja ennen kaikkea niittyheinää olisi riittävästi. Kraftmanin merkittävimmät kehitystyöt eli edistyksellisten kivinavettojen rakentaminen sekä aikansa laajimmat ojitus- ja suonkuivatushankkeet tähtäsivätkin viime kädessä karjanhoidon edellytysten parantamiseen, luonnonniittyjen lisäämiseen sekä sitä kautta lannoitetuotannon (lannan) kasvattamiseen. ${ }^{36}$ Näistä molemmista varsin

\footnotetext{
${ }^{31}$ Sacklén, "Framledne Professorens och Riddarens af Kongliga Wasa Orden Johan Kraftmans Lefwernes Beskrivning", no 30; Erkki Lehtinen, "Patriarkaalisen yhteiskunnan loppuaika n. 1721-1860", SuurUlvilan historia I osa, Porin mlk, Ulvila, Kullaa, Nakkila, 1967, 336; Louekari, Hyödyn politiikka, 145.

${ }^{32}$ Sacklen, "Framledne Professorens och Riddarens af Kongliga Wasa Orden Johan Kraftmans Lefwernes Beskrivning", no 30.

${ }^{33}$ Lehtinen, "Patriarkaalisen yhteiskunnan loppuaika", 330; Louekari, Hyödyn politiikka, 143.

${ }^{34}$ Sacklen, "Framledne Professorens och Riddarens af Kongliga Wasa Orden Johan Kraftmans Lefwernes Beskrivning", no 30 .

${ }^{35}$ Louekari, Hyödyn politiikka, 147-149.

${ }^{36}$ Kraftman kirjoitti vuoden 1765 valtiopäiville laajan katsauksen kaskeamisesta, jossa hän painottaa Suomen maaperän luonnetta ja kaskeamisen tekniikkaa. Klinge, Iisalmen ruhtinaskunta, 122-127.
} 
teknisistä hankkeistansa, kivinavettojen rakentamisesta sekä ojitushankkeista, hän myös julkaisi perinpohjaiset ja tarkat selvitykset.

Kraftmanin kehittämissä kivitalleissa ei ollut kyse tavanomaisista karjasuojista. Professori kehitti vuosia uudenlaista navettatilaa, jossa karjanhoito, lannan talteenotto ja varastointi järjestyivät manufaktuurimaisiksi prosesseiksi. Kraftman rakensi vuosien varrella kolme navettaa, joista viimeinen oli kolmikerroksinen. Navetan yläkerrassa säilytettiin heinää, joka voitiin pudottaa kätevästi alas keskikerroksessa pidettävien eläinten eteen. Vastaavasti alimpaan kerrokseen varastoitiin lanta, joka imeytettiin saveen. Navetassa oli myös riittävästi ikkunoita ja luonnonvaloa sekä kärryillä kuljettavat pariovet. Karjan ja hevosten hoidon työvaiheet oli tarkoin havainnoitu, suunniteltu, yksinkertaistettu ja kevennetty. Prosesseissa oli otettu huomioon ennennäkemättömällä tavalla työntekijät, työtilat, tuotanto, varastointi sekä materiaalien siirtely ja liikesuunnat. Lisäksi Kraftman kehitti materiaaliratkaisuja esimerkiksi rautaosien ruostumisen estämiseksi kosteassa kivinavetassa. Hänen kehittämällään lannan talteenotolla ja imeyttämistekniikalla saatiin aikaiseksi Koivistossa jopa 20 -kertaisia satoja. ${ }^{37}$

Kraftmanin artikkeli "Underrättelse om Stenmurars upsättande på Landsbygden”, joka käsitteli kivirakentamisen hyödyllisyyttä, julkaistiin Åbo tidningarissa vuonna 1771, pian lehden perustamisen jälkeen, jolloin Kraftmanin härkätallien ensimmäinen vaihe oli rakennettu. Artikkelissaan Kraftman otti kantaa metsänhaaskaukseen ja kivirakentamisen suosimiseen, jotka olivat varsin ajankohtaisia teemoja. Kirjoittaminen rationaalisista hankkeista sanomalehteen vastasi Kraftmanin tavoitteita hyödyllisen ja rationalistisen tiedon levittämisestä nopeasti ja tehokkaasti laajalle yleisölle. Kraftman julkaisi myös vuonna 1784 laajan ja tarkan selvityksen kivitalleistaan Kungliga Patriotiska Sällskapetin Hushålls Journalissa, jolloin hänen hankkeensa levisi valtakunnallisesti oppineiden tietoisuuteen. ${ }^{38}$

\section{Julkiseen keskusteluun osallistuminen provinssista käsin}

Julkisen keskustelun sfäärin muodostuminen vaatii Habermasin mukaan, jonkinlaisia demokraattisia instituutioita ja melko vakaita yhteiskunnallisia oloja. ${ }^{39}$ Tällaisten olosuhteiden voidaan katsoa alkaneen vähitellen muodostua vapaudenajalla Ruotsin valtakunnassa, jossa neljän säädyn valtiopäivät kokoontuivat säännöllisesti, paikallishallinto pitäjänkokouksineen kehittyi jatkuvasti ja jossa pyrittiin kohti painovapautta ja lopulta myös saavutettiin se. Habermasin julkisuusparadigmaa on yleensä tulkittu vai urbaanissa ympäristössä toteutuneeksi ilmiöksi, eikä sen ole katsottu toteutuneen provinsseissa tai maaseudulla. Kirjoittaminen ei kuitenkaan ole paikkaan sidottu toiminto, vaan lukemista ja kirjoittamista sekä yhteiskunnallista ajattelua ja kannanottoja voitiin harrastaa koko valtakunnassa.

Habermasin mukaan poliittisen julkisuuden rinnalle nousi kirjallinen julkisuus. Vapaudenajan Ruotsissa nämä ilmiöt kulkivat käsikädessä, kun päivän polttavista

\footnotetext{
${ }^{37}$ Johan Kraftman, "Underrättelse om Stenmurars upsättande på Landsbygden”, Tidningar utgifne af et Sällskap i Åbo 15.5.1771, no 9. Artikkelin jatko-osat julkaistiin myöhemmin samana vuonna numeroissa 22 ja 23. Markku Mattila, "Kraftmanin härkätalli", Sarka 6. Satakunnan museon vuosikirja, toim. Tiina Jäkärä \& Sirkka-Liisa Hakala, Satakunnan museo, Pori, 2000.

${ }^{38}$ Johan Kraftman, "Ladugårds-Byggnaden på Koivisto Rusthåll”, Hushållnings Journal 1784, no 10.

${ }^{39}$ Habermas, Julkisuuden rakennemuutos, 47-91; Huttunen, "Jürgen Habermasin yhteiskuntateoriat", 148; Sennefelt, Politikens hjärta, 20-21; Viitaniemi, Yksimielisyydestä yhteiseen sopimiseen, 32-33.
} 
poliittisista kysymyksistä kirjoitettiin ja argumentoitiin vapaasti lehdissä ja muissa painotuotteissa. Ruotsin valtakunnassa yhteiskunnallisesti kantaaottaviin kirjoituksiin innosti tietenkin hyötyajattelu, rationalismi sekä ajatus parhaan argumentin voitosta, jota erilaisilla kirjoituksilla yritettiin perustella. Sopivan areenan uusille ajatuksille tarjosivat nouseva lehdistö, pamflettien ja muiden pienpainatteiden jatkuva lisääntyminen sekä valtiopäivillä käydyt keskustelut. Rationalistisia, parhaimpia argumentteja ja ratkaisuja yhteiskuntapolitiikkaan sekä isänmaan taloudellisten olojen parantamiseen etsittiin myös erityisillä kirjoituskilpailuilla, joita julisti Kuninkaallinen tiedeakatemia.

Kraftmanin toiminta tuotti julkista keskustelua monella eri tasolla. Hän kirjoitti ja julkaisi 1760-luvun alkupuolella kaksi merkittävää yhteiskunnallista kirjasta, jotka käsittelivät Suomen olosuhteita ja maanviljelyksen erityislaatua, joita hän vertasi erityisesti Ruotsin keski- ja eteläosiin. Kraftmanin viesti oli selvä: Suomen ilmastoolosuhteissa oli keskityttävä maatalouden uudistamiseen ojittamalla peltoja sekä kuivattamalla soita, jotta saataisiin paremmin luonnonheinää karjalle ja parannettaisiin maatalouden perusedellytyksiä. Matti Klingen mukaan tämä Kraftmanin viitoittama, Suomen kehittämistä ajava linja otettiin kustavilaisella ajalla poliittiseksi ohjelmaksi. Seuraavassa kirjassaan Tankar om Svedjande, joka julkaistiin Tukholmassa valtiopäivien aikaan 1765, Kraftman keskittyi puolustamaan suomalaisten talonpoikien kaskeamisoikeutta ja vastusti esimerkiksi Hämeeseen asetettua kaskeamiskieltoa. ${ }^{40}$ Vaikka Kraftman oli itsekin tiukasti metsänhaaskausta vastaan ja pelkäsi aikalaisten tavoin Länsi-Suomen metsien loppuvan, hän ymmärsi, että kaskeaminen oli sallittava heikkotuottoisen maaviljelyn vaihtoehtona. Niin kauan kun yhteiskunnallisia edellytyksiä kuten vesiyhteyksien parantamista ja isojaon toteuttamista ei tapahtunut, ei kaskeamistakaan voitu lopettaa ilman, että se ajaisi talonpokaisperheitä kurjuuteen.

Vastaavasti samana vuonna Alavetelin kappalaisena toiminut Anders Chydenius julkaisi oman vastauksensa Tiedeakatemian kirjoituskutsuun "Mistä johtuu, että paljon ruotsalaisia muuttaa vuosittain maasta, ja millaisin säädöksin tätä voidaan parhaiten ehkäistä?”. Chydenius esitti vastauksessaan muun muassa laajaa sosiaalipoliittista kritiikkiä ja parannusehdotuksia eri ammatti- ja säätyryhmien asemaan. Tiedeakatemia ei Chydeniuksen vastausta palkinnut, ehkä juuri sen seikkaperäisen kritiikin ja argumentaation vuoksi, joten Chydenius julkaisi kirjoituksen itse vuonna 1765 Tukholmassa. ${ }^{41}$ Näin akatemian julkaisemaan kysymykseen annettu seikkaperäinen sosiaalipoliittinen vastaus levisi valtiopäivien aikana kirjasena. Siinä esitetyt ajatukset levisivät myös kasvokkain käytävinä keskusteluina Tukholman kahvihuoneissa ja seurueissa koko maasta kerääntyneiden valtiopäiväedustajien piirissä. Heidän välittämänään uudet poliittiset ajatukset saattoivat matkata Ruotsin valtakunnan provinsseihin, joissa Kraftmanin ja Chydeniuksen kuvaamat ilmiöt ja epäkohdat olivat varsin tuttuja. Keskusteluja ja ajatuksenvaihtoa voitiin jatkaa paikallistasolla.

Kraftmanin ja Chydeniuksen kaukana pääkaupungista laadittu kirjallinen tuotanto kuvaa varsin oivallisesti, miten poliittisen ja kirjallisen julkisuuden muodostuminen ei rajoittunut pelkästään Tukholmaan tai yliopistokaupunkeihin, vaan julkiseen keskusteluun oli mahdollista osallistua myös pienistä provinssikaupungeista ja maaseudulta käsin. Vaikka käsiteltävänä olevat yhteiskuntapoliittiset kysymykset olivat

\footnotetext{
${ }^{40}$ Klinge, Iisalmen ruhtinaskunta, $122-124$.

${ }^{41}$ Virrankoski, Anders Chydenius, 117-121; Anders Chydenius, Hvad kan vara orsaken, at sådan myckenhet svenskt folk flytter utur landet?, Stockholm, 1765.
} 
valtaisia, riitti julkisen keskustelun aktiiviseen ylläpitämiseen tiedon kulku postihevosten ja purjeveneiden tahtiin. Moniin ajankohtaisiin yhteiskunnallisiin kysymyksiin löytyi myös vastaus nimenomaan paikallistasolta, rahvaan elinpiiristä, josta sekä Kraftmanilla että Chydeniuksella oli varsin maanläheinen, vaikkakin toisistaan poikkeava, käsitys.

Ylipäätään joskus tutkimuksessa näkyy ajatellun, että lukevan yleisön suhteellinen vähälukuisuus oli esteenä lehdistön sekä erityisesti julkisen keskustelun synnylle maaseutuvaltaisessa Ruotsissa ja varsinkin Suomessa. ${ }^{42}$ Tällöin kuitenkin sivuutetaan se seikka, että Suomessa luettiin ruotsalaisia lehtiä ja vastaavasti esimerkiksi yliopistokaupungeissa luettiin taas laajalti ulkomaisia painotuotteita. Lisäksi unohdetaan varhaismodernin yhteiskunnan muut tiedonkulun väylät. Ruotsin valtio oli kirkon avulla luonut tehokkaan tiedotuskoneiston eli julkiset kuulutukset, jotka luettiin valtakunnan kirkoissa ja kappeleissa joka sunnuntai. Kruunun, erityisesti maaherrojen, masinoimien kuulutusten lisäksi saarnatuoleista luettiin yksityisiä ja myös kaupallisia ilmoituksia, mikä osittain korvasi lehdistön puutteen maaseudulla. ${ }^{43}$ Huomattavaa oli, että nämä kuulutukset ja uutiset tulivat kaiken kansan saataville kirkossa, säädystä, sukupuolesta ja varallisuudesta huolimatta, ilman lehden ostamisen tai lukutaitovaatimuksen haastetta. Ajankohtaista tietoa siirrettiin suomenkieliselle paikallistasolle eri tavoin, usein herrasväen välittämänä, mutta kuitenkin siten, ettei provinssien asukkaatkaan olleet täysin syrjässä valtakunnallisista julkisista keskusteluista.

\section{Kraftman yhteiskunnallisena vaikuttajana paikallistasolla}

Kraftmanin osuus paikallisen poliittisen kulttuurin kehityksessä oli merkittävä. AlaSatakunnassa hän aktivoi paikallisväestöä, osallistui paikallispolitiikkaan, keskusteli, argumentoi ja vei yhteiskuntaa kehittäviä uudistuksia väsymättä eteenpäin. Kraftman toimi everstiluutnantti O. J. Gripenbergin (1722-1803) ${ }^{44}$ kanssa Ulvilan seurakunnan kirkonesimiehenä ja kirkkoraadin jäsenenä. Kraftman teki Ulvilan paikallispolitiikassa useita aloitteita, kuten köyhäintuvan ja viljamakasiinin rakentaminen sekä Levanpellon (Kullaan) kappeliseurakunnan perustaminen. Tämän lisäksi hän toimi myös aktiivisesti ympäröivällä seudulla erilaisissa luottamustehtävissä ja hankkeissa. Kraftmanilla oli suhteita keskushallintoon, niin akatemiaan kuin lääninhallintoonkin. Esimerkiksi maaherra Jeremias Wallen (1693-1772) ${ }^{45}$ kävi Koivistossa Kraftmanin luona vierailulla,

\footnotetext{
${ }^{42}$ Huttunen "Jürgen Habermasin yhteiskuntateoriat", 150.

${ }^{43}$ Laine \& Ahokas, Hyödyllisen tiedon piirit; Manninen "Anders Chydenius ja maailman ensimmäisen tietämisen vapauden lain synty", Historiallinen Aikakauskirja 2006:4; Elisabeth Reuterswärd, Ett massmedium för folket. Studier i de allmänna kungörelsernas funktion i 1700-talets samhälle, Lunds Univerisitet, Lund, 2001.

44 Gripenberg mm. johti Kokemäenjoen koskenperkauksia 1757-61, 1762-63. Yrjö Kotivuori, Ylioppilasmatrikkeli 1640-1852: Odert Johan Gripenberg, Verkkojulkaisu 2005, URL: https://ylioppilasmatrikkeli.helsinki.fi/henkilo.php?id=U1174.

45 Piikkiöstä kotoisin oleva Jeremias Wallen toimi Turun ja Porin läänin maaherrana 1757-1769. Sittemmin maaherrat vaihtuivat melko usein. Yrjö Kotivuori, Ylioppilasmatrikkeli 1640-1852: Jeremias Wallén, Verkkojulkaisu 2005, URL: https://ylioppilasmatrikkeli.helsinki.fi/henkilo.php?id=5198.
} 
ja myöhemmin lääninkansliasta osoitettiin professorille luottamustehtäviä AlaSatakunnan alueella. ${ }^{46}$

Paikallishallinto ja hallinnolliset käytännöt kehittyivät melko nopeasti 1700-luvun jälkipuoliskolla. Vapaudenajan keskushallinto ja valtiopäivät tekivät useita uudistuksia, joiden täytäntöönpano tapahtui paikallistasolla, käräjäoikeudessa tai pitäjänkokouksessa tehdyillä päätöksillä. Vanhaan ruotsalaiseen hallintojärjestelmään kuului, että talonpoikien kanssa oli neuvoteltava ja saatava heidän suostumuksensa erilaisiin velvoitteisiin. Myös siitä, miten kulloinenkin uudistus tai hanke toteutettiin, piti keskustella ja sopia pitäjänmiesten kesken. ${ }^{47}$

Johan Kraftmanin toiminnasta ei voida kirjoittaa ilman, että mainitaan hänen laajaa suonkuivatushankettaan Ulvilassa ja Porissa. Pian Koiviston tilan hankittuaan (1748) hän lähti suunnittelemaan Lattomerensuon ojitusta ja kuivatusta. ${ }^{48}$ Vanhakantaisen maatalouden yksi heikkouksista oli lannoituksen ja heinän puutteen lisäksi riittämätön ojitus. Alavilla mailla pellot makasivat lumien sulamisvesien alla keväisin, ja tilannetta pahensivat myös Kokemäenjoen alajuoksulla koetut isot tulvat. Kraftman tiesi, että vaikka ojien kaivaminen alkeellisilla puisilla lapioilla hartiavoimin oli valtaisa urakka, kantaisi se lopulta tulosta, kun maa-alueen kuivuttua pystyttäisiin entiseltä suolta keräämään huomattavasti aikaisempaa enemmän luonnonheinää. Samasta syystä sekä maanomistusolojen selkeyttämisen takia Kraftman myös ajoi isonjaon nopeaa aloitusta. Kraftman aloitti kampanjoinnin Lattomerensuon kuivatuksen aloittamiseksi jo vuonna 1748. Hän laati tarkan selvityksen ja vetosi maaherraan. Kesti kuitenkin 12 vuotta ennen kuin silloinen maaherra Jeremias Wallen piti itse henkilökohtaisesti pitäjänkokouksen Ulvilan kirkossa suonkuivatushankkeen aloittamiseksi. Tilaisuudessa yritettiin ylipuhua maanomistajat ja talonpojat ryhtymään yhteiseen työhön vakuuttamalla heille ojituksesta koituvia hyötyjä. ${ }^{49}$ Asia ei kuitenkaan innostanut ulvilalaisia.

Kraftman aloitti kuitenkin syksyllä 1760 Lattomerensuon kuivatustyön. Hän lähetti työhön 11 Koiviston renkiä, mutta myöhemmin sovittuna päivänä alueen muista maanomistajista vain kuusi lähetti ojankaivuuseen miehen, tai oikeammin vanhoja miehiä tai nuoria poikia. $^{50}$ Kraftman ymmärsi tämän viestiksi hankkeen vastentahtoisuudesta, sillä talonpojilla oli tapana vältellä ylimääräisiksi kokemiaan velvollisuuksia ja yksi vastustuksen muoto oli näennäisesti suostua velvollisuuteen mutta lähettää lopulta työhön muita kuin parhaassa työiässä ja -kunnossa olevia miehiä. ${ }^{51}$ Kraftmanille tyypilliseen tapaan hän kiukustui ja turhautui tilanteesta, tarttui itse toimeen renkiensä rinnalla mutta kastui läpimäräksi ja sairastui. ${ }^{52}$

Ojitustyö eteni vähitellen, kun Kraftman jatkoi itsepäisesti omien osuuksiensa kaivuutöitä. Vuonna 1773 maaherra Rappe ilmoitti Porin raatihuoneella, että itse kuningas Kustaa III oli suonkuivatuksen kannalla. Tämän jälkeen kuivatustyöhön organisoitiin sekä Porin kaupunki että 78 Ulvilan taloa. Kraftmanista tehtiin projektin

\footnotetext{
${ }^{46}$ Ruuth, Porin kaupungin historia II, 507. Porin kaupungin ja lähiseudun verkostoista ja niiden toiminnasta ks. Jarkko Keskinen, Oma ja yhteinen etu. Kauppiaiden keskinäinen kilpailu ja yhteistyö Porin paikallisyhteisössä 1765-1845, Turun yliopisto, Turku, 2012.

${ }^{47}$ Viitaniemi, Yksimielisyydestä yhteiseen sopimiseen, passim.

${ }^{48}$ Louekari, Hyödyn politiikka, 150.

49 Kraftman, Berättelse Om Lattomeri Kärrs Utdikning; Lehtinen, "Patriarkaalisen yhteiskunnan loppuaika", 448.

${ }^{50}$ Lehtinen, "Patriarkaalisen yhteiskunnan loppuaika", 448.

${ }^{51}$ Viitaniemi, Yksimielisyydestä yhteiseen sopimiseen, 32-37.

${ }^{52}$ Lehtinen, "Patriarkaalisen yhteiskunnan loppuaika", 448.
} 
ylivalvoja. Raskaassa kaivuutyössä oli vuorollaan 15-60 miestä eri taloista, sen mukaan kuin saarnatuolista kuulutettiin. Työhön käytettiin lopulta ulvilalaisten osuudella 4821 työpäivää ja Porin kaupungin osuudella 2330 työpäivää. Kyseessä oli valtava kaivaustyö, jolla vesi ohjattiin kulkemaan Lattomerensuolta sekä Kokemäenjokeen että mereen. Suota kuivattamalla saatiin tuotettua niittyä, josta voitiin kerätä jopa 2000 aamia luonnonheinää eläimille. ${ }^{53}$ Ojitustyö hyödytti huomattavasti koko seutua, ja kuvaavaa on, että Kraftmanin muistokirjoituksessa nostettiin esiin nimenomaan hänen mittava työnsä Koivistossa sekä suonkuivatushankkeet ja ojitukset. Suonkuivatushanke nosti hänet vuonna 1775 Vaasan ritarikuntaan, ja vuonna 1778 hänet kutsuttiin Ruotsin tiedeakatemian jäseneksi. ${ }^{54}$

Toinen hieman vastaavan kaltainen hyödynaikakauden hanke oli Kokemäen kivikirkon rakentaminen, johon Kraftman nimettiin maaherran edustajaksi. Kirkot olivat julkisia rakennuksia, joiden kunnon tarkkailusta vastasivat maaherrat. Kirkot rakennettiin osittain julkisilla keräyksillä saaduilla varoilla, mutta pitkälti myös seurakuntalaisten veroluonteisten päivätöiden ja rakennusmateriaalitoimitusten avulla. Näin ollen sekä tuomiokapituli että maaherra osallistuivat kirkonrakentamisen valvontaan. Kraftman pyydettiin maaherran edustajaksi paikallistasolle. Kokemäen uuden kirkon suunnittelu osui Kustaa III:n antaman kivikirkkojen rakentamista suosivan lainsäädännön saranakohtaan. Kokemäkeläiset olivat varautuneet rakentamaan vain suuren puukirkon, mutta kivikirkkomääräys muutti suunnitelmat täysin. Niinpä keskushallinnon edustajana toimineelle Kraftmanille jäi tehtäväksi taivutella kokemäkeläiset huomattavasti kalliimman ja hankalamman kivirakentamisen kannalle sekä etsiä sopiva paikka uudelle entistä suuremmalle ja painavammalle kivikirkolle..$^{55}$

Kokemäen uuden kivikirkon paikan etsintä vaati paljon neuvottelua, taivuttelua sekä odottamista ja turhautumista - sekä professorin jo tutuksi tullutta kiukustumista ennen kuin saavutettiin koko yhteisöä hyödyttävä lopputulos. Kraftman paneutui tehtävään huolella. Jo ensimmäisestä pitäjänkokouksesta syntyi 18-sivuinen raportinomainen pöytäkirja, jonka professori itse laati keskushallinnolle. Kraftmanin tavoitteena oli etsiä kirkolle paikka, jossa olisi hyvä ja kestävä maaperä ja johon kivirakentaminen voitiin toteuttaa mahdollisimman järkevästi. Paikan piti olla myös kirkon arvolle sopiva, mutta myös kaikkien seurakuntalaisten kohtuullisesti saavutettavissa, sillä Kraftmanin mukaan kaikilla oli yhtäläinen oikeus saapua kirkkoon. Vielä kivikirkon rakennusvaiheessa käytiin oikeutta päätöksentekoon liittyvistä prosesseissa, mutta näihin Kraftman ei enää liittynyt, vaikkakin myös hänen toiminnastaan valitettiin kuninkaalle paikkakiistan kireimmässä vaiheessa ${ }^{56}$ Kivikirkko edusti hyödynaikakauden ajattelua, sillä kivimateriaalin käytön ajateltiin säästävän metsävaroja. Kivikirkon ajateltiin myös kestävän puukirkkoa pidempään. Joka tapauksessa pitkälti Kraftmanin johtaman varsin riitaisan ja monipolvisen suunnitteluja päätöksentekoprosessin lopputulemana oli, että paikallisen päätöksenteon ja

\footnotetext{
${ }^{53}$ Sacklen, "Framledne Professorens och Riddarens af Kongliga Wasa Orden Johan Kraftmans Lefwernes Beskrivning" no 32.

${ }^{54}$ Virrankoski, "Kraftman, Johan".

${ }^{55}$ RA, ÖIÄ till Kungl. Maj:t. 1778, vol. 317, Yli-intendentti Adelcrantz KM:lle 15.5.1778, Kokemäen pitäjänkokouksen ptk 8.6.1777; Viitaniemi, Yksimielisyydestä yhteiseen sopimiseen, 154-173.

${ }^{56}$ RA, Landshövdingarnas skrivelser till Kungl. Maj:t, Finland, Åbo och Björneborgs län 1778-1781, vol. 34, maaherra Fredenskiöld ja Turun tuomiokapituli KM:lle 17.2.1779, maaherran edustajan Johan Kraftmanin selvitys, ei päiväystä; Viitaniemi, Yksimielisyydestä yhteiseen sopimiseen, 213-218.
} 
hallintokulttuurin käytäntöjä arvioitiin ja sen ohella harjoiteltiin uusia, entistä avoimempia toimintatapoja.

Kolmantena esimerkkinä Kraftmanin paikallispoliittisesta toiminnasta on hautaamistavan muutoksen läpivieminen. Vielä 1700-luvun jälkipuoliskolla oli yleisenä tapana haudata ruumiit kirkon lattian alle. Tästä aiheutui kuitenkin monenlaista haittaa. Kirkon lattian alla olevista haudoista levittäytyi kirkkotilaan kalmanhaju, mitä alettiin pitää 1700-luvun kuluessa erittäin vaarallisena terveydelle. Paha haju saattoi myös estää ihmisiä osallistumasta jumalanpalvelukseen sekä sen jälkeen pidettäviin pitäjänkokouksiin. Kraftman kävi hyödynajan hengessä sekä todennäköisesti myös pietistisen vakaumuksen pohjalta taisteluun ikiaikaista perinnettä vastaan. Hän perusteli kirkkoon hautaamisen lopettamista vuonna 1767 "terveen moraalin, politiikan ja järkevän harkinnan sekä kristillisen velvollisuuden ja vastuullisuuden tähden”. Ongelmana kuitenkin oli, että kirkossa sijaitsevat hautapaikat olivat osoitus myös sosiaalisesta asemasta ja arvostetuimmista hautasijoista käytiin kauppaa. Näin ollen muutos ei tapahtunut nopeasti, vaikka asteittain kirkkohautauksia rajoitettiinkin. Lisäksi muun muassa päätettiin, että kirkkoa tuuletettaisiin kesäkaudella aina ennen jumalanpalveluksia. ${ }^{57}$

Kraftman kyllästyi lopulta siihen, ettei kirkkohautaamisesta Ulvilassa luovuttu kokonaan, vaikka hän oli ollut ajamassa menestyksekkäästi samaa asiaa myös Kullaan, Porin ja Kokemäen kirkoissa. Niinpä hän vielä vuonna 1778 laati tiukkasävyisen selvityksen tästä "hirvittävästä ja pahasta tavasta" ja esitti varsin perusteellisesti erilaisia hyötynäkökulmia, miksi kirkkohautaaminen oli lopettava. Kraftman totesi, että hän oli jopa itse valmis korvaamaan omasta kukkarostaan lunastettujen hautapaikkojen arvon, jotta tapa saataisiin päätettyä. Viime kädessä Kraftman oli sitä mieltä, että kaikilla oli oikeus osallistua jumalanpalveluksiin minkään häiritsemättä. ${ }^{58}$ Moraalin ja kristinopin tunteminen kuului nimittäin kaikille säädystä ja asemasta huolimatta. ${ }^{59}$

\section{Johtopäätökset: Kraftman oikean tiedon tuottajana ja välittäjänä sekä yhteiskunnan rakentajana}

Johan Kraftmanin toimintaa leimasivat fysiokratia ja patriotismi varsin tyypillisessä 1700-luvun vahvaa edistysuskoa huokuvassa muodossa. Hänen toimintansa lomittui yhteiskunnan eri tasoille keskushallinnosta aina karjapiikojen töiden järjestämiseen saakka. Kraftman pyrki vaikuttamaan suoraan valtiopäivien toimintaan ja valtakunnan politiikkaan julkaisemalla ajankohtaisia tekstejä. Kraftman havainnoi, teki kokeita ja kirjoitti tuloksistaan tarkkoja selvityksiä, joiden tarkoituksena oli vaikuttaa sekä päätöksentekoon että maatalouden käytäntöihin. Kirjoituksillaan hän osallistui ajankohtaisiin yhteiskuntapoliittisiin keskusteluihin, joissa esitettiin ja argumentoitiin yhteiskunnan kehittämisen kannalta parhaita mahdollisia uudistuksia ja toimintatapoja.

57 Ulvilan seurakunta, Ulvilan kirkonarkisto, II Ca, pitäjänkokouksen pöytäkirjat 1746-1792, pitäjänkokouksen pöytäkirja 15.3.1767; Ella Viitaniemi, "Hautauskäytäntöjen muutos Länsi-Suomen maaseudulla osana 1700-luvun edistysajattelua", Thanatos 2018:2, 39-42.

58 Ulvilan seurakunta, Ulvilan kirkonarkisto, II Ca, pitäjänkokouksen pöytäkirjat 1746-1792, pitäjänkokouksen pöytäkirja 24.5.1778; Viitaniemi, "Hautauskäytäntöjen muutos Länsi-Suomen maaseudulla”, 42-47.

${ }^{59}$ Kraftman, Tal om läsningsverket, 24. "Jag kan derhos säga, at en hop grundsanningar i Moralen eller Sedoläran hafwa uti mit tycke blifwit ansedde af den nödwändigheten, at äfwen den enfaldigast bonde dräng borde hafwa en tydelig kunskap derom". 
Hänen työnsä tunnustettiin ja lopulta hänet nimettiin tiedeakatemian jäseneksi, mikä osaltaan avasi hänelle julkaisukanavia.

Kaiken julkaisemisen takana Kraftmanilla oli varsin käytännönläheinen suhde maatalouteen ja ympäröivään yhteiskuntaan, jonka elinolosuhteita ja taloudellisia mahdollisuuksia hän pyrki parantamaan. Kraftman teki havaintoja maataloustyöstä arjen keskellä ja etsi parempia ratkaisuja esimerkiksi karjanhoitoon, niittyheinän korjaamiseen ja ojitukseen liittyen. Kraftman oli visionääri, mutta myös valmis tarttumaan itse työhön.

Isänmaan taloudellista etua oli ajateltava ja toteutettava kaikessa. Asioita oli kehitettävä, toteutettava käytännössä ja siirrettävä tieto eteenpäin sekä valtakunnallisina julkaisuina että puheina niin Porin triviaalikoulun oppilaille kuin Ala-Satakunnan maanomistajille ja talonpojille. Valistus ei näyttäytynyt Krafmanille kaunopuheina tai sukkelina sananparsina salongeissa, vaan se oli ennen kaikkea suo-ojissa kahlaamista ja kokeiluja lehmänlannan talteen ottamiseksi sekä keskusteluja ja argumentointia paikallisten ihmisten kanssa. Olennaista Kraftmanille oli, että rationalistinen ajattelu ja oikea tieto siirtyi tasolta toiselle, akateemisista kirjoituksista aina alasatakuntalaisille talonpojille saakka, jotka elivät maataloudesta ja kokivat sen kehitysvaiheet konkreettisesti.

Kansalaisyhteiskunnan (borgerligt samhälle) varhainen rakentaminen tapahtui Kraftmanin mukaan myös koulutuksen kautta. Toimiessaan Porin triviaalikoulun rehtorina hän ymmärsi, että koulutusta pitää eriyttää, sillä nuoret miehet suuntasivat yhteiskunnan eri osa-alueille. Tärkeää oli, että niin papeilla, virkamiehillä, upseereilla kuin kauppiailla oli koulutus, jonka pohjalta heihin oli istutettu oikean tiedon intressi. Kraftmanin antama uudenlainen luonnon- ja taloustiedon opetus tähtäsi siihen, että taloudellinen toimeliaisuus viriäisi nuorten miesten kautta paikallistasolla. Olennaista oli, että oikea tieto levisi, ja juuri kasvava keskiluokka tai herrasväki oli tärkeässä roolissa uusien menetelmien levittäjänä ja yhteiskunnan uudistajana.

Kraftmanin pääasiallinen yhteiskunnallinen toiminta tapahtui pienessä provinssikaupungissa Porissa sekä Ulvilan pitäjässä. Kuitenkin hän osallistui valtakunnalliseen keskusteluun ja hänen toimintansa tunnustettiin Tukholmassa. Poliittisen julkisuuden ja varhaisen kansalaisyhteiskunnan rakentaminen tapahtui siis paikallistasolla - hovin, valtiopäivien tai yliopistojen ulkopuolella. Kraftmanin toiminta osoittaa konkreettisesti, miten maaseutu ja paikallistason poliittiset areenat sidottiin mukaan valtakunnallisen julkisen keskustelun ja yleisen mielipiteiden muodostumisen piiriin.

Kraftman näki ihmisen pitkälti ohjailtavana taloudellisena resurssina, jonka velvollisuutena oli toimia ahkerasti yhteiskunnan ja isänmaan hyväksi. Kraftman näki kuitenkin maatalouden kehittämisen yhteiskunnallisena ja taloudellisen toimena ja mahdollisuutena, jonka edistäminen auttoi myös yksilöitä ja perheitä. Kraftman tiesi ja tunsi talonpoikien köyhyyden ja hankalat elinolosuhteet ilmaston ja kruununverojen kurituksessa, ja hän teki erilaisia toimia olosuhteiden parantamiseksi. Merkittävimpiä toimia oli suonkuivatushanke, joka lisäsi huomattavasti niittyalaa ja mahdollisti suuremman määrän karjaa. Kraftmania kiinnostivat myös muut yhteiskunnalliset ja paikallispoliittiset hankkeet, joilla voitiin parantaa ympäröivää elinympäristöä, kuten köyhäintuvan ja viljamakasiinin rakennuttaminen ja ruumishautauksien lopettaminen Ulvilan kirkossa. Hän toimi myös maaherran edustajana Kokemäen kivikirkkohankkeessa, jossa hän toi esille lukuisia hyötynäkökulmia ja argumentoi 
voimakkaasti parhaina pitämiensä ratkaisujen puolesta. Kraftman visioi, miten maataloutta voitiin tehostaa ja miten yhteiskuntaa piti rakentaa, ja hän oli myös itse valmis toimimaan aktiivisesti ja resurssejaan säästelemättä tavoitteiden saavuttamiseksi. Ei siis ollut ihme, että hänen kirjoituksistansa paistaa joskus läpi tietynlainen turhautuminen yhteiskunnan hidastempoisuuteen ja muutosvastarintaan. Kuitenkin hän ahkeroi itse julkisten mielipiteiden ja asenteiden muuttamiseksi sekä modernin yhteiskunnan rakentamiseksi.

Ella Viitaniemi

FT, tutkija

Historia, filosofia ja kirjallisuus

Tampereen yliopisto

ella.viitaniemi (apud) tuni.fi

\section{Arkistolähteet:}

Kansallisarkisto, Turku

Turun arkkihiippakunnan tuomiokapitulin arkisto (TATA), kirjekirja BI: 16 (1748).

Riksarkivet, Tukholma

Landshövdingarnas skrivelser till Kungl. Maj:t, Finland, Åbo och Björneborgs län 1778-1781, vol. 34 .

Överintendentsämbetet (ÖIÄ) till Kungl. Maj:t. 1778, vol. 317.

Ulvilan seurakunta

Ulvilan kirkonarkisto, II Ca, pitäjänkokousten pöytäkirjat 1746-1792.

\section{Painetut lähteet:}

Chydenius, Anders, Hvad kan vara orsaken, at sådan myckenhet svenskt folk flytter utur landet?, Stockholm, 1765.

Gadd, Pehr Adrian, Satakunnan kihlakuntain pohjoisosan taloudellisen kuvaamisen yritys, joka käsittää huomautuksia maantieteen, muinaismuistojen, fysiikan, luonnonhistorian ja talouden ym. aloilta tarpeellisine piirroksineen (Observationes physico-oeconomicae, in septentrionali praetura territorii superioris Satagundiae collectae, 1747), suom. Kaapo Murros, Tampereen historiallinen seura, Tampere, 1946.

Kraftman, Johan, "Ladugårds-Byggnaden på Koivisto Rusthåll". Hushållnings Journal 10/1784. Kungliga Patriotiska Sällskapet, Stockholm, 1784.

Kraftman, Johan, Tal om läsningsverket, Hållne vid examina anniversaria i Björneborg trivial-schola, Lars Salvius, Stockholm, 1751.

Kraftman, Johan, "Underrättelse om Stenmurars upsättande på Landsbygden", Tidningar utgifne af et Sällskap i Åbo, 1771:9, 1771:22, 1771:23.

Kraftman, Johannes, Berättelse Om Lattomeri Kärrs Utdikning: Författad år 1782, Kongl. tryckeriet, Stockholm, 1785.

Sacklén, Lars, "Framledne Professorens och Riddarens af Kongliga Wasa Orden Johan Kraftmans Lefwernes Beskrivning”, Åbo tidningar 1792: 30-34. 


\section{Kirjallisuus}

Förvaltningshistorisk ordbok: "borgerligt samhälle", URL: http://fho.sls.fi/uppslagsord/4816/borgerligt-samhalle/.

Gustafsson, Harald, "De överlappande pusslen. Om partikularistiska och multietniska konglomeratstater i det tidigmoderna Europa", Maktens mosaik. Enhet, särart och självbild i det svenska riket, red. Max Engman \& Nils Erik Villstrand, Svenska litteratursällskapet i Finland \& Atlantis, Helsingfors \& Stockholm, 59-73.

Habermas, Jürgen, Julkisuuden rakennemuutos. Tutkimus yhdestä kansalaisyhteiskunnan kategoriasta, suom. Veikko Pietilä, Vastapaino, Tampere, 2004.

Huttunen, Raimo, "Jürgen Habermasin yhteiskuntateoriat", 1900-luvun saksalainen yhteiskuntateoria, toim. Ilkka Kauppinen, Miikka Pyykkönen \& Olli-Pekka Moisio, Gaudeamus, Helsinki, 2019, s. 148-170.

Ihalainen, Pasi, Agents of the people. Democracy and popular sovereignty in British and Swedish parliamentary and public debates, 1734-1800, Brill, Leiden, 2010.

Ihalainen, Pasi, Michael Bregnsbo, Karin Sennefelt \& Patrik Winton (eds), Scandinavia in the Age of Revolution. Nordic political cultures 1740-1820, Ashgate, Farnham, 2016.

Karonen, Petri, Pohjoinen suurvalta. Ruotsi ja Suomi 1521-1809, WSOY, Helsinki, 1999.

Kemiläinen, Aira, "Nationalismi ja patriotismi Ranskan vallankumouksen aatemaailmassa", Historiallinen Aikakauskirja 1989:4, s. 275-295.

Keskinen, Jarkko, Oma ja yhteinen etu. Kauppiaiden keskinäinen kilpailu ja yhteistyö Porin paikallisyhteisössä 1765-1845, Turun yliopisto, Turku, 2012.

Klinge, Matti, Iisalmen ruhtinaskunta. Modernin projekti sukuverkostojen periferiassa, Suomalaisen Kirjallisuuden Seura, Helsinki, 2006.

Klinge, Matti, Professoreita, Otava, Helsinki, 1990. (2. painos).

Kotivuori, Yrjö, Ylioppilasmatrikkeli 1640-1852: Jeremias Wallén, Verkkojulkaisu 2005,

URL: https://ylioppilasmatrikkeli.helsinki.fi/henkilo.php?id=5198, noudettu 16.10.2020.

Kotivuori, Yrjö, Ylioppilasmatrikkeli 1640-1852: Johan Kraftman, Verkkojulkaisu, 2005, URL: https://ylioppilasmatrikkeli.helsinki.fi/henkilo.php?id=5888, noudettu 22.9.2020.

Kotivuori, Yrjö, Ylioppilasmatrikkeli 1640-1852: Odert Johan Gripenberg, Verkkojulkaisu 2005, URL:

https://ylioppilasmatrikkeli.helsinki.fi/henkilo.php?id=U117, noudettu 16.10.2020.

Laasonen, Pentti, Suomen kirkon historia 2. Vuodet 1593-1808, WSOY, Porvoo, 1991.

Laine, Esko M. \& Minna Ahokas (toim.), Hyödyllisen tiedon piirit. Tutkimuksia papistosta, rahvaasta ja tiedon rakentumisesta 1700-luvulla, Suomalaisen Kirjallisuuden Seura, Helsinki, 2018.

Laine, Kirsi, Maatalous, isojako ja talonpoikainen päätöksenteko Lounais-Suomessa 1750-1850, Suomen maatalousmuseo Sarka, Loimaa, 2020.

Lehtinen, Erkki, "Patriarkaalisen yhteiskunnan loppuaika n. 1721-1860", Suur-Ulvilan historia I osa, Porin mlk, Ulvila, Kullaa, Nakkila, 1967, s. 304-618.

Lindberg, Bo, Den antika skevheten. Politiska ord och begrepp i det tidig-moderna Sverige, Kungliga vitterhets historie och antikvitets akademien, Stockholm, 2006. 
Lindberg, Bo, "Den förmoderna offentligheten. En begreppshistorisk exposé", Förmoderna offentligheter. Arenor och uttryck för politisk debatt 1550-1830, red. Leif Runefelt \& Oskar Sjöström, Nordic Academic Press Lund, 2014, s. 21-38.

Louekari, Sami, Hyödyn politiikka. Kokemäenjoen ympäristöhistoriaa 1720-1850, Turun yliopisto, Turku, 2013.

Manninen, Juha, "Anders Chydenius ja maailman ensimmäisen tietämisen vapauden lain synty", Historiallinen Aikakauskirja 2006:4, s. 470-484.

Manninen, Juha, Valistus ja kansallinen identiteetti. Aatehistoriallinen tutkimus 1700luvun Pohjolasta, Suomalaisen Kirjallisuuden Seura, Helsinki, 2000.

Marjanen, Jani, Den ekonomiska patriotismens uppgång och fall. Finska hushållningssällskapet i europeisk, svensk och finsk kontext 1720-1840, Helsingin yliopisto, Helsinki, 2013.

Mattila, Markku, "Kraftmanin härkätalli", Sarka 6. Satakunnan museon vuosikirja, toim. Tiina Jäkärä \& Sirkka-Liisa Hakala, Satakunnan museo, Pori, 2000, s. 40-69.

Miettinen, Riikka \& Ella Viitaniemi (toim.) Reunamailla. Tilattomat Länsi-Suomen maaseudulla 1600-1800, Suomen Kirjallisuuden Seura, Helsinki, 2018.

Niemelä, Jari, Vain hyödynkö tähden? Valistuksen ajan hyötyajattelun, luonnontieteen ja talouspolitiikan suhde Pehr Adrian Gaddin elämäntyön kautta tarkasteltuna, Suomen Historiallinen Seura, Helsinki, 1998.

Nordin, Jonas, Ett fattigt men fritt folk. Nationell och politisk självbild i Sverige från sen stormaktstid till slutet av frihetstiden, Symposion Brutus Östlings bokförlag, Eslöv, 2000 .

Nurmiainen, Jouko, Edistys ja yhteinen hyvä vapaudenajan ruotsalaisessa poliittisessa kielessä, Suomalaisen Kirjallisuuden Seura, Helsinki, 2009.

Paloposki, Toivo, Suomen talouden kehittäminen 1750-1760-lukujen valtiopäiväpolitiikassa, Suomen Historiallinen Seura, Helsinki, 1976.

Pihlaja, Päivi Maria, Tiedettä pohjantähden alla. Pohjoisen tutkimus ja Ruotsin tiedeseurojen suhteet Ranskaan 1700-luvulla, Societas Scientiarum Fennica, Helsinki, 2009.

Reuterswärd, Elisabeth, Ett massmedium för folket. Studier $i$ de allmänna kungörelsernas funktion i 1700-talets samhälle, Lunds Universitet, Lund, 2001.

Ruuth, J. W., Porin kaupungin historia II, 1558-1809. Uuden suomenkielisen laitoksen toimittanut Mauno Jokipii. Porin kaupunki, Pori, 1958.

Saastamoinen, Kari, "Johdatus poliittisiin käsitteisiin uuden ajan alun Ruotsissa", Käsitteet liikkeessä. Suomen poliittisen kulttuurin käsitehistoria, toim. Matti Hyvärinen, Jussi Kurunmäki, Kari Palonen, Tuija Pulkkinen \& Henrik Stenius, Vastapaino, Tampere, 2003, s. 19-62.

Sennefelt, Karin, Politikens hjärta. Medborgarskap, manlighet och plats $i$ frihetstidens Stockholm, Stockholmia, Stockholm, 2011.

Skuncke, Marie-Christine \& Henrika (red.) Riksdag, kaffehus och predikstol. Frihetstidens politiska kultur 1766-1772, Svenska litteratursällskapet i Finland, Helsinki \& Atlantis, Stockholm, 2003.

Suolahti, Gunnar, "Miten Pietari Kalm tuli professoriksi?", Historiallinen Aikakauskirja 1910:1, s. 15-28.

Talvitie, Petri, Kyläomistuksesta yksityiseen maanomistukseen. Isojako LänsiUudellamaalla 1700-luvulla, Helsingin yliopisto, Helsinki, 2013. 
Talvitie, Petri, Taistelu perintökirjasta. Talonpojat, aateli ja kruununtilojen perinnöksiostot 1700-luvun Suomessa ja Ruotsissa, Suomalaisen Kirjallisuuden Seura, Helsinki, 2020.

Teerijoki, Ilkka, Nälkävuosien turva? Pitäjänmakasiinit Suomessa 1700-luvulla, Suomen Historiallinen Seura, Helsinki, 1993.

Walta, Matti, Virkamiehiä. Lääninhallinnon virkamiehet 1721-1708, Suomen sukututkimusseura, Helsinki, 2005.

Viitaniemi, Ella, "Hautauskäytäntöjen muutos Länsi-Suomen maaseudulla osana 1700luvun edistysajattelua", Thanatos 2018:2, s. 29-59.

Viitaniemi, Ella, "Muurarimestari Kustaa Stenman ja katumaton maailma. Pietismi, kirjoittaminen ja kokemuksen siirtäminen länsisuomalaisella maaseudulla 1700luvun jälkipuoliskolla”, Eletty historia. Kokemus näkökulmana menneisyyteen, toim. J. Annola, V. Kivimäki, A. Malinen, Vastapaino, Tampere, 2019, s. 75-112.

Viitaniemi, Ella, Yksimielisyydestä yhteiseen sopimiseen. Paikallisyhteisön poliittinen kulttuuri ja Kokemäen kivikirkon rakennusprosessi 1730-1786, Tampereen yliopisto, Tampere, 2016.

Winton, Patrik, Frihetstidens politiska praktik. Nätverk och offentlighet 1746-1766, Uppsala universitet, Uppsala, 2006.

Virrankoski, Pentti, Anders Chydenius. Demokraattinen poliitikko valistuksen vuosisadalla, WSOY, Helsinki, 1986.

Virrankoski, Pentti, "Kraftman, Johan", Kansallisbiografia-verkkojulkaisu, Suomalaisen Kirjallisuuden Seura, Helsinki, 2000.

Wolff, Charlotta, Noble conceptions of politics in eighteenth-century Sweden (ca 17401790), Suomalaisen Kirjallisuuden Seura, Helsinki, 2008.

Östlund, Joachim, Lyckolandet. Maktens legitimering i officiell retorik från stormaktstid till demokratins genombrott, Sekel, Lund, 2007. 